\title{
The Key Success Female Entrepreneurs Batik Jonegoro in Indonesia
}

\author{
Nur Laily ${ }^{1} \&$ Dewi Urip Wahyuni ${ }^{1}$ \\ ${ }^{1}$ Sekolah Tinggi Ilmu Ekonomi Indonesia, (STIESIA) Surabaya, Indonesia \\ Correspondence: Nur Laily, Sekolah Tinggi Ilmu Ekonomi Indonesia, (STIESIA) Surabaya, Indonesia. \\ Received: January 26, 2018 \\ Accepted: February 12, $2018 \quad$ Online Published: February 23, 2018 \\ doi:10.5430/ijba.v9n2p67 \\ URL: https://doi.org/10.5430/ijba.v9n2p67
}

\begin{abstract}
The success of female entrepreneurs Batik need hard work, self-efficacy, innovation and ambition behavior. The purpose of this research is to find out the role of self-efficacy and innovative behavior towards the success of female entrepreneurs Batik in Bojonegoro. This research uses descriptive and quantitative analysis research design. The population in this research are all female batik entrepreneur in Bojonegoro. The sample collection technique has been carried out by using non-probability sampling in which samples are determined based on certain criteria in accordance with the research purpose. The numbers of samples are 32 respondents. The Data collection techniques has been done by using questionnaires and conducting interviews. The obtained data are analyzed by using Partial Least Square (PLS) which is the equation model of Structural Equation Modeling (SEM) which is based on components or variants. The results of the research show that: self efficacy gives influence to the success of female batik entrepreneurs. Self-efficacy gives influence to the innovative behavior of female batik entrepreneur. Innovative behavior gives influence to the success of female batik entrepreneurs, Self-efficacy gives indirect influence to the success of female entrepreneurs through the mediator i.e. innovative behavior.
\end{abstract}

Keywords: self-efficacy, innovative behavior, the success of female entrepreneurs

\section{Introduction}

Successful female entrepreneurs are not something which occur by chance, beyond that success there must be hard work, confidence, innovation, creative and great intentions within the success itself. The desire or interest of someone to do entrepreneur can be seen from the entrepreneurial behavior itself. According to Global Entrepreneurship Monitor ( GEM ) in Rani and Norashidah ( 2017) the involvement of women in entrepreneurship area are not only contribute for the development of country but also reduce the level of poverty all over the world. The nature of entrepreneurship is associated with self-behavior that is more likely to focus on the self or have the self-efficacy so that the achieved success comes from the results of strength and self-effort, not caused by fate. An entrepreneur must have self-efficacy. According to Bandura in Drnovsek, (2009) et. al. self-efficacy involves individuals' beliefs regarding their capabilities to attain goals and control positive and negative cognitions that an entrepreneur has during the process of starting-up a business. Self-efficacy is a belief in a person's ability to manage and perform the actions necessary to produce an achievement. Individuals with a high level of self-efficacy will do their best for achieving the desired things. People who have high entrepreneurial motivation will tend to innovate in business activities, especially in the handicraft industry, then the product innovation will greatly affect the success. One of the industries that many enthused by female entrepreneurs in Indonesia is the home industry that is Batik Industry. Since inaugurated batik became world treasure from UNESCO on October 2, 2009, as the original heritage of Indonesia, batik to host in their own country. All Indonesian people are proud to wear batik shirt.

Each region in is able to produce batik in accordance with the typical characteristics of each region. According to Pinasti and Wiwiek ( 2016 ) said that Batik small and medium industry is an industry that is experiencing rapid development and has great potential to be developed at this time. In Indonesia, Central Java is one of the areas of Batik small and medium enterprises ( SMEs) center which has great potential. Beside the Pekalingan and Solo batik, in the southern region of the central Java province, there are centers of batik industry which has a distinctive and attractive pattern. Besides that, Bojonegoro also has batik industry, it known as Batik Jonegoro. Batik is a home production, therefore most of the actors are female. Currently, Jonegoro batik is growing and qualified that can distinguish batik Jonegoro with other batik. The Barriers of batik industry Jonegoro is a managerial problem that is closely related to the culture and customs of local communities and traditional marketing strategies. However, the entrepreneurial female of batik in Bojonegoro believe in their ability that the business will run successfully. 
Self-efficacy is a very important entrepreneurial characteristic to run its business. Besides, innovative incremental behavior is needed such as product innovation, service and management. Besides that, support from local government of Bojonegoro is needed for continuity and superiority of Jonegoro batik. Therefore the role of self-efficacy (Self-efficacy) and innovative behavior is indispensable for the success of batik entrepreneurial female in Bojonegoro. This study aims to determine the effect of self-efficacy on the success of batik entrepreneurial female, the influence of self-efficacy on the innovation behavior of female entrepreneurial batik, the influence of innovation behavior on the success of female entrepreneurial batik and indirect influence self-efficacy against the success of female entrepreneurs through the mediator of this behavior. This research uses descriptive and quantitative descriptive research design.

The results of this study showed that batik entrepreneurial women have high self-efficacy that supports the success in running their business. The self-efficacy of female batik entrepreneurs encouraged them to behavior innovatively, and the behavior of innovation has an influence on the success of batik entrepreneurial women in Bojonegoro.

\section{Literature Review}

\subsection{Self-Efficacy}

Self-Efficacy is a belief in a person's ability to manage and perform the actions necessary to produce an achievement. According to Bandura in Campo ( 2010 ) defined that self-efficacy as the task specific consideration of perceived fitness to perform a paticular activity. In the case entrepreneurial self-efficacy may be comparised of deliberation of those tasks that relate to the initiation and development of new ventures. High self-efficacy in a person makes people like things that are challenging and balanced with high endurance so as to achieve the desired goals. Individuals who have high self-efficacy will be very easy in facing challenges. Individuals do not hesitate because he has a belief that is full of his ability. A person with a high self-efficacy is sure to succeed. Otherwise, someone with low self-efficacy often gives up in the face of adversity. According to Bandura in Hsiao, et. al. (2011) individuals with a high sense of self efficacy belief are more likely to have higher levels of performance and higher commitment to tolerate frustration and to remain task-focused when obstacles arise. Accoding to Bandura dalam Drnovsek, et. al. ( 2009 ) psychological process in self efficacy (Self-efficacy) that plays a role in the individual there are four namely Cognitive processes, motivation, affection, and selection.

\subsection{Innovative Behavior}

Innovative behavior according to Wess and Farr (De Jong \& Kemp, 2003) are all individual behaviors directed toward generating, introducing, and .applying novelty, which are useful in various organizational levels. Bryd and Bryman (2003) say that there are two dimensions that underlie innovative behavior that is creativity and risk taking. Amabile, et. al (De Jong \& Kamp, 2003) that all innovations start from a creative idea. The innovation that suits innovative behavior is incremental innovation. The focus of innovative behavioral research is a key factor of incremental innovation (De Jong \& Kemp, 2003). Innovative behavior in this study are all individual behaviors directed towards generating and implementing new things, which are useful in various levels of the organization; Which consists of two dimensions of creativity and risk taking and innovation process is incrementa.

\subsection{The Success of Female Enterpreneurs}

Success is a subjective concept, in that the measure of success is determined by the perception of the culprit (Simpson et. al., 2004). According to and Riding in Rani ( 2017 ) said that has been interpreted the success among women entrepreneurs through balance between work and life, religious attachment and sustain personal and customer relationship. Research conducted by Justo, et. al. (2006) explains that women entrepreneurs and male entrepreneurs have different perceptions about success, such as: early motivation to become entrepreneur and family factors, especially parental status. Female entrepreneurs define success if they can control their beliefs, build good relationships with their customers and do something meaningful, while a male entrepreneur defines success from achieving goals. Vanessa (2008) defines the success of women entrepreneurs who run home based entrepreneurs based on quality relationships with consumers, personal satisfaction, fulfillment satisfaction and the ability to balance work and family responsibilities. Simply the success or success of individuals running a business defined by the ability to be able to run the business operations, otherwise the failure is defined by the inability to run a business that ended with the cessation of business operations. It is supported by Omar in Rani and Norashidah ( 2017 ) that entrepreneurs need to have strong characteristics to become a succesful in future. Success is a subjective concept, in the sense that each entrepreneur has their own perception of the meaning of the word "success". This study combines previous research, Sunday. S. Babalola (2014). Research entitled Women Entrepreneurial Innovative Behavior: The Role of Psychological Capital. The results show that women with high self-efficacy and internal locus of control 
have higher entrepreneurial innovative behavior than women with low self-efficacy and locus of control. This study also shows that there is a significant relationship between women with high education and low educated women on innovation behavior. Lu Hong Da, et. al. (2013). Research entitled Relation between Entrepreneurial Leadership and Innovative

Behavior: The Mediating Effect of Entrepreneurial Self Efficacy and the moderating effect of openness to experience and extraversion. The results show that entrepreneurial leadership positively affects innovative behavior through mediation of self-efficacy of entrepreneurship. Mikail Moment et. al. (2014). The research result shows that self-efficacy is positively related to employee's innovative behavior.

\section{Conceptual Framework}

According to Bandura in Campo ( 2010 ) defined that self-efficacy as the task specific consideration of perceived fitness to perform a paticular activity. In the case entrepreneurial self-efficacy may be comparised of deliberation of those tasks that relate to the initiation and development of new ventures. High self-efficacy in a person makes people like things that are challenging and balanced with high endurance so as to achieve the desired goals, the success of his business. High efficacy encourages one to innovate, Innovative behavior according to Wess\& Farr ( De Jong \& Kemp, 2003) are all individual behaviors directed toward generating, introducing, and applying novelty, which are useful in various organizational levels

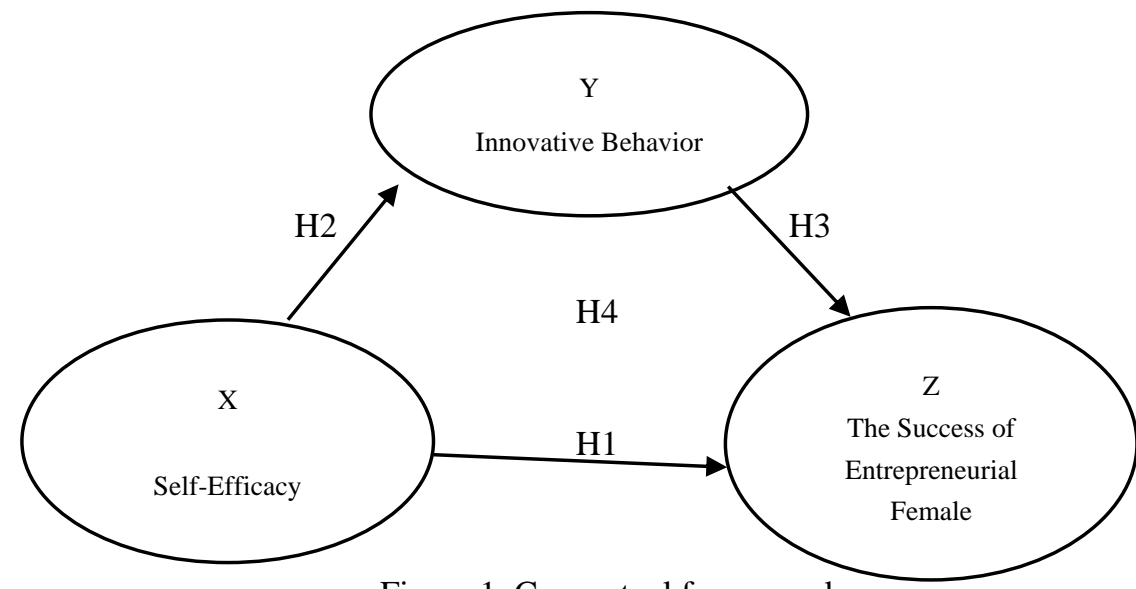

Figure 1. Conceptual frame work

\section{H1. Self efficacy affects the Success of female Batik Entrepreneurs}

H2. Self-efficacy affects the innovative behavior of the Success of female Batik Entrepreneurs

H3. Innovative behavior affects the Success of female Batik Entrepreneurs

H4. Self-efficacy has an indirect effect on the Success of female Batik Entrepreneurs through innovative behavioral mediator.

\section{Research Methods}

This research uses descriptive and quantitative descriptive research design. Population in this research is all female entrepreneur of batik in Bojonegoro that exist in Bojonegoro regency which amount 35 female. Sampling technique using non probability sampling that is the sample is determined based on certain criteria appropriate to the purpose of research. The criteria used are the age of business actors above or equal to 17 years, the age of business is longer or equal to 2 th, his business is registered in the industrial service. The number of samples according to the study criteria was 32 respondents.

\subsection{Research Variables}

The variables used in this study are self-efficacy (X), Innovative Behavior $(\mathrm{Z})$ and success of women entrepreneur (Y). 
Self-efficacy (X) is the response of respondents about the confidence in the individual to manage themselves positively and carry out the duties as a woman entrepreneur. Self-efficacy variable is measured by using 4 (four) indicators which have been developed by Corsini in Buduran 2007 i.e. Cognitive, Motivation, Affection and Selection. The highest score is obtained by the subjects which indicate the existence of self-efficacy is high. Conversely, the lowest score which indicates the lack of self-efficacy is possessed by the subject.

Innovative Behavior $(Z)$ is the response of respondents about the ability to introduce, apply and improve the idea of new ideas that bring profit in trade. This variable is measured by 5 (five) indicators developed by Kleysen and Street (2001) as follows: exploring opportunities, generating ideas, Formative investigation, Championing, Application.

The success of entrepreneurial women (Y): a response of respondents about the ability to control trust, build good relationships with customers and do something meaningful.

This variable is measured by 5 (five) indicators developed by Riyanti (2004) as follows: quality life, freedom, network building, job satisfaction, balance of family responsibilities and work. Measurement of variables using Likert scale, with scoring scores as follows: Value 5 for the answer strongly agree, Value 4 for answer agree, Value 3 , for neutral answer, Value 2, for answer disagree, Value 1, for answer strongly disagree.

The success of entrepreneurial women (Y): a response of respondents about the ability to control trust, build good relationships with customers and do something meaningful. This variable is measured by 5 (five) indicators developed by Riyanti (2004) as follows: quality life, freedom, network building, job satisfaction, balance of family responsibilities and work.

Measurement of variables using Likert scale, with scoring scores as follows: Value 5 for the answer strongly agree, Value 4 for answer agree, Value 3, for neutral answer, Value 2, for answer disagree, Value 1, for answer strongly disagree.

\subsection{Research Instrument}

The research instruments used in this study are questionnaires and documentation. To ensure the accuracy and consistency of the research subject data, the questionnaire will be tested so that the compiled instrument can be used to capture the data accurately

\subsection{The Data Analysis Techniques}

Data analysis using Partial Least Square (PLS) approach is a model of Structural Equation Modeling (SEM) equation based on component or variant. According to Ghozali (2006) the goal of Partial Least Square (PLS) is to help researchers for predictive purposes. The formal model defining the latent variable is the linear aggregate of the indicators. Weight estimate for creating latent variable score components in can be based on outer model and inner model.

The Outer model shows the Convergent validity of the measurement model with the reflective indicator model judged by correlation between the score item/component score with the construct score calculated by the PLS. According to Chin (1998) in Ghozali (2009), the reflective measure is said to satisfy if the scale of measuring the loading values of 0.5 to 0.60 is considered sufficient. Another method to assess discriminant validity is to compare the root value of Average Variance Extracted (AVE). Recommended AVE values should be greater than 0.50 according to Fornnel and Larcker (1981) in Ghozali, (2009).

Inner models illustrate the relationship between latent variables based on substantive theory. In the study using the PLS model can be started by looking at R-square for each dependent latent variable. The interpretation is the same as the interpretation of the regression. Changes in R-square values can be used to assess the effect of particular latent variables on latent dependent variables whether they have substantive effects. (Ghozali, 2006)

In this study there are intervening variables, namely Innovation Behavior. According to Baron and Kenny (1986) in Ghozali (2009) a variable is called an intervening variable if the variable influences the relationship between the predictor variable (independent) and the criterion variable (dependent). Testing of hypothesis mediation can be done by procedure developed by Sobel (1982) and known by Sobel test.

\section{Result and Discussion}

\subsection{Respondent Characteristics}

Characteristics of respondents showed description of respondents covering gender, age of business, age of respondent, number of children and education. Respondent or unit of analysis in this research is batik entrepreneur woman in Bojonegoro. This research data by circulating questionnaires that have been distributed to 32 respondents 
female entrepreneurial batik in Bojonegoro who meet the criteria of the study sample. Overview of the general description of the subject of research based on the characteristics of respondents are as follows: 32 respondents $(100 \%)$ are women so that respondents are on target according to research objectives. $34 \%$ of respondent's age is productive age that is 35-46 years so that answer given in questionnaire according to condition of respondent. The age of business conducted by respondents $34 \%$ for 4 years shows that respondents have experience in running the business. As many as $47 \%$ of respondents have children of 2 orang, this indicates that the respondent should be able to divide the time between business and family. The dominance of respondent education is high school $41 \%$, that with high education hence respondent easy to understand question in questionnaire

\subsection{The Description of Research Variables}

Variables of this research consist of self-efficacy as independent variable, innovation behavior as mediating and success of woman entrepreneur of batik as dependent variable. These variables are measured by using Likert scale with a score of 1 to 5 so it can be obtained that the average value of respondents' answers on each indicator of the latent variable shows quite high and moderate. This can be seen in Table 1 is as follows:

Table 1.The avereage value of respondents' answer

\begin{tabular}{ccc}
\hline Description & Average & Standard Deviation \\
\hline Self-efficicacy & & \\
X1 & 4.095 & 0.607 \\
X2 & 4.235 & 0.499 \\
X3 & 4.060 & 0.470 \\
X4 & 3.875 & 0.616 \\
X & 4.067 & 0.548 \\
Z1 & & \\
Z2 & 4.060 & 0.631 \\
Z3 & 3.985 & 0.648 \\
Z4 & 4.115 & 0.601 \\
Z5 & 4.205 & 0.600 \\
Z6 & 4.020 & 0.587 \\
Innovative Behavior & 4.077 & 0.613 \\
Y1 & & \\
Y2 & 3.845 & 0573 \\
Y3 & 3.985 & 0.603 \\
Y5 & 3.795 & 0.541 \\
The Success of W. Entrepreneur & 3.920 & 0.568 \\
\hline
\end{tabular}

Sources: Processed data

\subsection{The Result Of Data Analysis}

The daya analysis in this research has been conducted by using Structural Equation Modeling (SEM) with Smart PLS software (Partial Least Square). There are 2 models of PLS Path Modeling data analyses i.e. Outer model and Inner model.

\subsection{Outer Model Evaluation}

Outer Model is also known as outer relation or measurement model which specifies the relationship between the variables which have been studied by using their indicators.

\subsection{Convergent Validity}

Convergent validity of the measurement model with reflexive indicator can be seen from the correlation between score items/indicators with their constraint scores. Individual indicators are considered to be reliable if they have a correlation value above 0.7. However, on the scale development research, loading 0.50 to 0.60 is still acceptable (Ghozali, 2002: 40). The result of the correlation between indicators and their construct as seen in the ouput below: 
Tabel 2. Convergent validity

\begin{tabular}{ccccc}
\hline & $\begin{array}{c}\text { original sample } \\
\text { estimate }\end{array}$ & mean of subsamples & $\begin{array}{c}\text { Standard } \\
\text { deviation }\end{array}$ & T-Statistic \\
\hline $\begin{array}{c}\text { Self-efficicacy (X) } \\
\text { X.1 }\end{array}$ & 0.710 & 0.784 & & \\
X.2 & 0.593 & 0.602 & 0.076 & 9.296 \\
X.3 & 0.764 & 0.745 & 0.224 & 2.646 \\
X.4 & 0.813 & 0.823 & 0.090 & 8.498 \\
Innovative Behavior (Z) & & & 0.068 & 12.019 \\
Z1 & 0.902 & 0.906 & & \\
Z2 & 0.770 & 0.803 & 0.028 & 32.258 \\
Z3 & 0.868 & 0.882 & 0.037 & 21.085 \\
Z4 & 0.775 & 0.700 & 0.016 & 52.616 \\
Z5 & 0.722 & 0.704 & 0.182 & 4.257 \\
The $\quad$ & & 0.126 & 5.743 \\
Entrepreneur (Y) & & & & \\
Y1 & & & & 13.860 \\
Y2 & 0.757 & 0.794 & 0.055 & 15.722 \\
Y3 & 0.813 & 0.824 & 0.052 & 12.425 \\
Y4 & 0.760 & 0.792 & 0.077 & 20.791 \\
Y5 & 0.810 & 0.800 & 0.065 & 0.041 \\
\hline
\end{tabular}

Source: Processed data

The results of the Convergent validity data in Table 2 show the Self-efficacy Variable (X) is measured by using 4 dimensions of overall measurement having convergent validity value above 0.5 , then the 4 dimensions that measure Self Efficacy (X) are declared valid as the constituent measure. Innovation Behavior $(\mathrm{Z})$ as it is measured by using 5 dimensions, it is concluded that the whole has fulfilled the validity requirement as a measuring instrument, because the convergent validity value of each dimension is above 0.5. The last construct is the Success Women Entrepreneurs (Y) variable with 5 indicators. Each has a convergent validity value above 0.5 so it is declared valid.

\subsection{Discriminant Validity}

The output in Table 3 that all constructs are validity criteria.

Table 3. Cross loading

\begin{tabular}{cccc}
\hline & Self-Efficacy $(\mathbf{X})$ & Innovative Behavior $(\mathbf{Z})$ & The Success of Women Entrepreneurs $(\mathbf{Y})$ \\
\hline $\mathbf{X . 1}$ & 0.710 & 0.448 & 0.845 \\
$\mathbf{X . 2}$ & 0.593 & 0.235 & 0.184 \\
$\mathbf{X . 3}$ & 0.764 & 0.358 & 0.310 \\
$\mathbf{X . 4}$ & 0.813 & 0.452 & 0.888 \\
$\mathbf{Z 1}$ & 0.335 & 0.491 & 0.757 \\
$\mathbf{Z 2}$ & 0.662 & 0.514 & 0.813 \\
$\mathbf{Z 3}$ & 0.283 & 0.507 & 0.760 \\
$\mathbf{Z 4}$ & 0.327 & 0.456 & 0.810 \\
$\mathbf{Z 5}$ & 0.645 & 0.781 & 0.842 \\
Y1 & 0.333 & 0.902 & 0.856 \\
Y2 & 0.383 & 0.770 & 1.054 \\
Y3 & 0.454 & 0.868 & 0.854 \\
Y4 & 0.392 & 0.775 & 0.711 \\
Y5 & 0.557 & 0.722 & 0.490 \\
\hline Source
\end{tabular}

Source: Processed data 


\subsection{Average Variance Extracted (AVE)}

AVE describes the average variance or discriminant extracted on each indicator, so that the ability of each item to divide measurements with others can be known. An AVE value equal to or above 0.50 indicates a good convergent

Table 4. The value of AVE and composite reliability

\begin{tabular}{ccc} 
& Average variance extracted (AVE) & Composite Reliability \\
\hline Self-Efficacy $(\mathbf{X})$ & 0.525 & 0.814 \\
Innovative Behavior $(\mathbf{Z})$ & 0.656 & 0.905 \\
The Success of W. Entrepreneur $(\mathbf{Y})$ & 0.635 & 0.897 \\
\hline
\end{tabular}

Source: Processed data

In Table 4 we got the AVE value for Self-Efficacy $(X)$ variable of 0,525; Variable of Innovation Behavior (Z) equal to 0,656 and the Success of Women Entrepreneur (Y) equal to 0,635. At the critical limit of 0.5 then the indicators on each cone have converged with the other items in one measurement.

Another test is the composite reliability of the block of indicators that measure the construct (Ghozali, 2002: 25). The goal is to know the consistency of the questions given to the respondents. Based on Table 3 it can be explained that from the provision of composite reliability it can be declared all the constructs studied meet the criteria of composite reliability, because the value $>6$ so that each construct is able to be positioned as a research variable. It indicates that the composite of all variables has adequate internal consistency in measuring the measured latent / constructed variables so that they can be used in further analysis.

\subsection{Inner Model Evaluation}

Inner model is also called inner relation, structural model and substantive theory specifies the relationship between research variables.

Inner Model Test is used to evaluate the relationship between latent constructs as hypothesized in the study. Based on the PLS output, the following drawings are obtained:

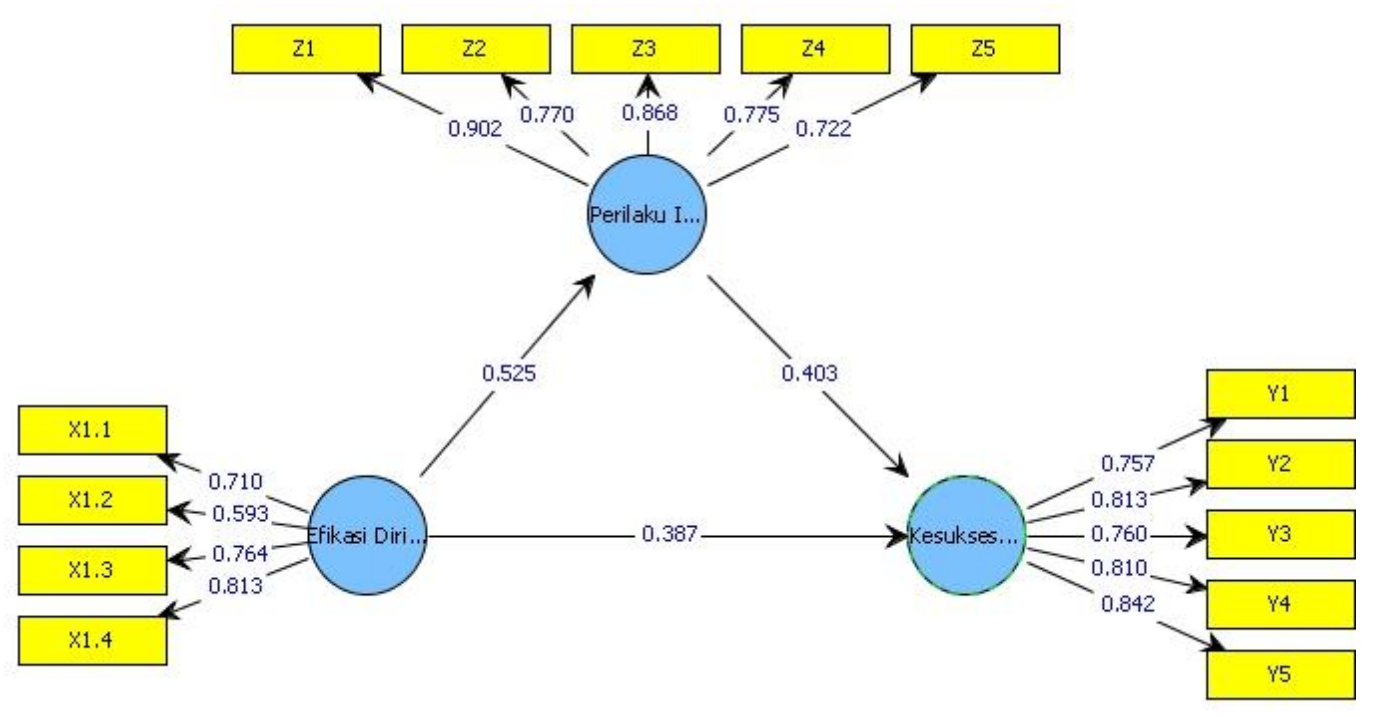

Figure 2. PLS research model 
The result of inner weight value in Figure 2 shows that Innovation Behavior $(Z)$ is influenced by Self-Efficacy (X). While the Success Women Entrepreneurs is influenced by Self Efficacy (X), and Innovation Behavior (Z) shown in hypothesis test.

\subsection{Hypothesis Test}

Table 5. Inter constructs table

\begin{tabular}{llccccc}
\hline & & $\begin{array}{c}\text { original sample } \\
\text { estimate }\end{array}$ & $\begin{array}{c}\text { mean of } \\
\text { subsamples }\end{array}$ & $\begin{array}{c}\text { Standard } \\
\text { deviation }\end{array}$ & T-Statistic & Conclusion \\
\hline $\begin{array}{l}\text { Self-efficacy } \quad(\mathbf{X}) \rightarrow \text { The } \\
\text { women entreprenurs }(\mathbf{Y})\end{array} \quad$ success $\quad$ of & 0.387 & 0.457 & 0.117 & 3.314 & accepted \\
$\begin{array}{l}\text { Self-efficacy } \\
\text { Behavior }(\mathbf{Z})\end{array} \quad(\mathbf{X}) \rightarrow$ Innovative & 0.525 & 0.529 & 0.106 & 4.960 & Accepted \\
$\begin{array}{l}\text { Innovative behavior }(\mathbf{Z}) \rightarrow \text { the success } \\
\text { of women entrepreneurs }(\mathbf{Y})\end{array}$ & 0.403 & 0.391 & 0.111 & 3.636 & Accepted \\
\hline
\end{tabular}

Source: Processed data

Based on Table 5 can be interpreted on each path coefficient is as follows:

1). Self-efficacy $(X)$ has a positive effect on the success of batik entrepreneurial female in Bojonegoro. This can be seen in T-statistics of 3.314 greater than 1.96 so hypotheis 1 is proven and accepted.

2). Self-efficacy (X) positively influence the behavior of innovation (Z). It can be seen that $\mathrm{T}$ statistics of 4,960 are greater than 1.96 so hypothesis 2 is proven and accepted.

3). Behavior innovation (Z) positive effect on the success of female entrepreneurs (Y). It can be seen that T-statistics of 3,636 are greater than 1.96 so the third hypothesis is proven and accepted.

4). Hypothesis Testing to 4 (four) indirect influence between Self Efficacy to the success of female entrepreneurs through Behavior of innovation. The influence of mediation test is done by using Sobel formula. The amount of coefficient of indirect influence Self-efficacy to the success of female entrepreneurs through Innovation Behavior is a multiplication of the effect of Self Efficacy towards Innovation Behavior and Innovation Behavior to the success of female entrepreneurs, so it has been obtained as follows:

$$
\begin{array}{rl}
P 12 & `=P 1 . P 2 \\
& =(0.525)(0.403) \\
& =0.216
\end{array}
$$

The magnitude of standard error indirect influence of Self-efficacy towards the success of female Entrepreneurs through Innovation Behavior, obtained as follows:

$$
\begin{aligned}
\mathrm{Se12} & =\sqrt{P 1^{2} \cdot S e 2^{2}+P 2^{2} \mathrm{Se} 1^{2}+S e 1^{2} \cdot S e 2^{2}} \\
& =\sqrt{(0,525)^{2}(0,112)^{2}+(0,747)^{2}(0,057)^{2}+(0,057)^{2}(0,112)^{2}} \\
& =0,073
\end{aligned}
$$

Thus the $\mathrm{t}$ test value is obtained as follows:

$$
t=\frac{P 12}{S 12}=\frac{0,216}{0,073}=2,959
$$

The value of $t$ is 2.96> 1.96 which means that the mediation parameter is significant. Thus, the Indirect Effect model Self-efficacy for the success of female entrepreneurs through Innovation Behavior is acceptable, so Hypothesis 4 is proven and accepted

\subsection{Structural Model Test (Inner Model)}

In assessing the model with Partial Least Square (PLS) begins by looking at R-Square for each dependent latent variable. Changes in R-Square values can be used to assess the effect of certain latent independent variables on latent dependent variables whether they have substantive effects. Endogenous latent variables in the structural model with $\mathrm{R} 2$ yield of 0.67 indicate that the "good" model, $\mathrm{R} 2$ of 0.33 indicates that the "moderate" model, R2 of 0.19 indicates that the model is "weak" (Ghozali, 2009). The PLS output as described below: 
Table 6. Model feasibility test

\begin{tabular}{lc}
\hline \multicolumn{1}{c}{ Descriptions } & R-square \\
\hline Self-Efficacy (X) & \\
Innovative Behavior (Z) & 0.275 \\
The Success of Women Entrepreneur (Y) & 0.475 \\
\hline
\end{tabular}

Source: processed data

The latent variable, Self-Efficacy $(X)$ which influences the Innovation Behavior $(Z)$ variable in the structural model has an R2 value of 0.275 which indicates that the model is "Weak". The latent Variables, Self-Efficacy, and Innovation Behavior which give influence to the the success of women entrepreneur variable in the structural model has an $\mathrm{R} 2$ value of 0.475 which indicates that the model is "moderate".

The evaluation of PLS model is also done by testing the value of Q2 Predictive Relevance.

The suitability of the structural model can be proved as follows:

$$
\begin{aligned}
& Q^{2}=1-\left[\left(1-R_{1}{ }^{2}\right)\left(1-R_{2}{ }^{2}\right)\right]=1-[(1-0.275)(1-0.475)]=1-[(0.725)(10.475) \\
& =1-[(0.725)(0.525)] \\
& =1-0.381 \\
& =0.619
\end{aligned}
$$

From the results of Q2 is 0.619 which means that the value is above zero point five, it can be concluded that the structural model is eligible to be used as research.

\section{Discussion}

\subsection{The Influence of Self-efficacy to the Success of female Batik Entrepreneurs}

The results of the first hypothesis show that there is influence Self-Efficacy to the Successful of female Batik Entrepreneur in Bojonegoro is equal to 0.387. These results prove that self-efficacy gives influence to the success of women batik entrepreneurs, although the influence of self-efficacy is small but this is the basic capital to achieve success. Self-efficacy definition is a belief that is in each individual to achieve what she wants and the goal, especially in the face of business and can also be used to plan a business for the future to be done. A businessman or business woman need to have high self-efficacy to face the business competition which is very fast. The results of this study showed that batik entrepreneurial women have high self-efficacy that supports the success in running their business. Batik entrepreneurial women have high self-efficacy to manage their business well and profitably, besides that entrepreneurial batik sure able to complete its responsibility and ready to face business challenge. Self-efficacy entrepreneur batik female is the initial capital to achieve its success. One indicator of the success of female entrepreneurs in running their business is not to leave their duties as a wife and housewife who must take care of household necessities. The female batik entrepreneur can divide the time between business and their household, it can be run because the batik industry is a home business. All activities which are related to the process of making batik and selling is done at home. Although the place of business is at home the female have self confident of being able to compete with its competitors and able to achieve its target. High Self-efficacy of women batik entrepreneurs has made women entrepreneurs easy to get along and many networking. The ability of these female entrepreneur to develop themselves and their business through their network with gradually in order to their business is going to successful.

The results of this research support the research of Cuningham (in Riyanti 2003,7) that the success of someone in running a small and medium business is related to the nature of personality traits, such as the desire to do good work, the desire to succeed, self-motivation, trust and positive thinking, patient. These results support Bandura (1990) that self-efficacy is the belief of a person in his ability to do the specific job he is responsible for. The results of this research support the research of Campo (2010) saying that women seem to feel as capable of performing entrepreneurial tasks as man. This research does not support the research of Zhao (2005) gender was not related to entrepreneurial intentions and entrepreneur than men.

\subsection{The Influence of Self-efficacy to the Innovative Behavior of Women Batik Entrepreneurs}

The results of the second hypothesis shows that there is influence self-efficacy to innovative behavior of female batik entrepreneurs is equal to 0,525 . These results indicate that self-efficacy gives influence to the innovation behavior of 
female batik entrepreneurs. The confidence of female batik entrepreneurs encourage their innovatie behavior in order to make the business which has been running can produce quality

products and have competitive advantage. These results indicate that the self-efficacy of female batik entrepreneurs encouraged them to behave innovatively. Female batik entrepreneurs should behave innovatively, especially in the face of the globalization era. The innovative behavior of women batik entrepreneur is supported by self-efficacy and it is also supported by the level of education and the age of female batik entrepreneurs business. The level of education and knowledge will give influence to the development of female entrepreneur soul to innovate their business. In this study the dominant education of respondents are SMA and Diploma and age of business run for more than 2 years. Experience during running his business to make entrepreneurial women batik able to face business challenges, one of which must be done is to innovate products and innovation management company. Highly educated entrepreneurial women have a strong will to expand their knowledge, especially in batik making, motif design and coloring. Information and ideas of new ideas obtained through seminars, workshops and internet media to make women entrepreneurial batik able to behave creatively to get the best idea and implements in design and product of quality batik. Self-confidence and capabilities have made entrepreneurial women able to accept ideas and ideas of others and select the information obtained. Research on the determinants that shape innovative behavior is tested by Scott and Bruce (1994) against workers at a research and development center in the United States. The study examines the effect of individual attributes, leaders, group work directly on innovative behavior as well as the influence of individual attributes, leaders, and group work partially on innovative behavior through a psychological climate to innovate. The results of this study are similarly put forward by Stein \& Woodman (Brazeal \& Herbert, 1997) said that innovation is a successful implementation of creative ideas. The results of this study support the research of Momeni, et. al. states that self-efficacy has an impact on innovative job behavior at social security organization in Ardabil province.

\subsection{The Influence of Innovative Behavior on the Success of Women Batik Entrepreneurs}

The results of the third hypothesis shows that there Innovative behavior has an effect on the success of entrepreneurial women batik that is equal to 0.403 . These results indicate that the behavior of innovation has an influence on the success of batik entrepreneurial women in Bojonegoro. Innovative behavior is needed to run the business so that the products produced in accordance with consumer tastes and achieved business success. Behavioral innovation is a series of activities or efforts in the face of work that involves ways and ideas of new ideas to complete the task. Innovative behavior is very supportive for the success of entrepreneurial women batik without innovative then the batik business will not be successful, with innovative behavior then the success of the business can be achieved. Innovative behavior of entrepreneurial batik makes batik Jonegoro able to compete with batik that has been widely known of Yogyakarta batik, batik Solo, batik Madura, batik pekalongan, batik Cirebon, and batik from other regions in Indonesia. Innovative behavior of entrepreneurial women is also supported by cultural background, entrepreneurial woman of batik in Bojonegoro majority is Javanese ethnic that upholds the value of east culture that is polite, keep ethics, painstaking and likes to help others. In addition, the age of entrepreneurial women is 35 years old which shows the maturity of women to behave innovatively in running their business and running her business over 2 years to make entrepreneurial women have a lot of experience in doing it. Background of life is what shapes the character of women in business is patient, painstaking, meticulous, sensitive to the environment, cooperative and have a networking. It make the women successful to run a business. This is a specific female to distinguishes women and men to reach their success in their business. These results indicate that the success of entrepreneurial women can not be separated from the behavior of women's innovation in the background of culture, age of business and experience. Sandjaja and Riyanti (2004) who stated that innovative behavior contributed significantly to the success of the business. The ability to innovate a female against something that can help a person become creative and foster an intention to entrepreneurship The results of this study support the research Idris, A (2008) said the entrepreneurial innovativeness of these women is associated with their age, educational attainment, type and location of business, annual income and number of employees. Innovative women entrepreneurs tend to be in their 40s and have at least pre-university education.

\subsection{Self-efficacy Has an Indirect Influence to the Success of Female Batik Entrepreneur through Innovative Behavioral as the Mediators}

The result of the fourth hypothesis shows that self-efficacy has an indirect effect through the mediator of innovation behavior. These results indicate that self-efficacy can affect the success of entrepreneurial women, if the self-efficacy of business female followed by innovation behavior, the success of entrepreneurial women is increasing. Self-efficacy is very important for entrepreneurial female to run their business because self-efficacy is to build a basic belief in order 
to achieve a success, to achieve a success must be followed by innovative entrepreneurial behavior. Innovative in a product is very important done for the achievement of corporate goals. Individuals do an innovation because they are inspired from existing products or environments, then developed to produce a new innovation. An innovation made by entrepreneurs will be able to influence the success of the entrepreneur itself female batik Jonegoro entrepreneurs have high self-efficacy, female batik entrepreneurs are sure to be able to run the business and achieve the success of its business. Strong abilities and beliefs are supported by education, age and experience to make women entrepreneur innovative to make their business a success. Innovative behavior that has been done by female batik entrepreneurs for the success of their business is to conduct innovation activities on the motives and colors so that the result of the batik has various motives and colors in accordance with the tastes of batik Jonegoro consumers. Currently there are 13 motives which are the typical batik Jonegoro before 2013 batik motif Jonegoro only 9 batik motives. Jonegoro batik motifs reflect the culture and distinctive. If in 2009 only 9 motives are sanctioned by the local government. So in 2013 the motive was developed into 14 motifs. Batik motifs in bojonegoro reflect the culture and production of agricultural products, oil and gas and wood craft typical of Bojonegoro regency. In 2016, batik entrepreneur also make the latest innovation that is batik woven with batik Jonegoro motives. This is done because to distinguish between one product with other products so that will be achieved a success especially for woman entrepreneur of batik and perpetrator of batik Jonegoroan in general. This innovation makes batik Jonegoro growing and has a competitive advantage. The results of this study are in accordance with Wess \& Farr's opinion (in De Jong \& Kemp, 2003) all individual behaviors directed toward generating, introducing, and applying new things, which are useful in various organizational levels. The results of this study support Vanessa (2008) that the success of female entrepreneurs who run home based entrepreneurs based on quality relationships with consumers, personal satisfaction, fulfillment satisfaction and the ability to balance work and family responsibilities. Simply the success or success of individuals running a business defined by the ability to be able to run the business operations, otherwise the failure is defined by the inability to run a business that ended with the cessation of business operations. The results of this study support Sunday.S.Babalola.2014 research. Research entitled female Entrepreneurial Innovative Behavior: The Role of Psychological Capital. The results showed that women with high self-efficacy and internal locus of control were rated higher on innovative entrepreneurial behavior than women with low self-efficacy and external locus of control.

There is a significant relationship between highly educated women and poorly educated women.

\section{Conclusion}

Batik entrepreneurial female have high self-efficacy so as to manage their business well and profitably, besides that female batik entrepreneur able to complete its responsibility and ready to face business challenge. Self-efficacy of female batik entrepreneur is the initial capital to achieve its success. One indicator of the success of female entrepreneurs in running their business is not to leave their duties as a wife and housewife who must take care of household necessities. Innovative behavior of female batik entrepreneur is very important especially in facing the era of globalization. Innovative behavior of female entrepreneurial batik in addition supported by self-efficacy is also supported by the level of education and age of female entrepreneurial business of batik. The level of education and knowledge will affect the development of entrepreneurial female's soul to innovate. Innovative behavior of female batik entrepreneurs make batik Jonegoro different from other batik area and able to compete with batik which has been known namely Yogyakarta batik, Solo batik and other regions existing in Indonesia. Background culture, education, age and characteristics of women who encourage to behave innovation to achieve business success. Self-definition is very important for female entrepreneurs to run their business because self-efficacy is to build a basic belief in order to achieve a success, to achieve a success, it must be followed by Innovative behavior of female entrepreneur. Confidence and innovation behaviors undertaken by female entrepreneurs make batik business growing and successful. Innovative Behavior is done that adds patterns, batik motifs and colors, the latest innovation of batik weaving so that Jonegoro batik growing and has the advantage to compete.

\section{Acknowledgement}

Thanks to The Honorable.

Directorate of Research and Community Service, Directorate General Strengthening Research and Development Ministry of Research. Technology and higher education of the Republic of Indonesia, which has provided research grants.

Chairman of Sekolah Tinggi Ilmu Ekonomi Indonesia / STIESIA Surabaya and Head of LP2M who has helped facilitate researchers in completing the study. 
Bupati, Head of District Bojonegoro and Head of Department of Industry and Labour of Bojonegoro Regency who have helped and facilitated the research

\section{References}

Adair, J. (1996). Effective Innovation. How to Stay Ahead of the Competition. London: Pan Books.

Alma, B. (2013). Kewirausahaan. Bandung. Alfa Beta.

Ashykin, N.A.A., Nurul, A.A., Noreen, N.A.A., Fariha, S.M., \& Afifah, H.M. (2016). Determining the Factors to Engage in Batik Business: A Study among Batik Entrepreneurs in East Cost Malaysia. International Journal of Management Sciences, 7(5), 273-286.

Bandura, A. (1997). Self-efficacy: The exercise of control. New York: W. H. Freedman and Company.

Byrd, J., \& Brown, P.L. (2003). The Innovation Equation. Building Creativity and Risk Taking in Your Organization. San Fransisco: Jossey-Bass/Pfeiffer. Retrieved from www.pfeiffer.com

Campo, J.L.M. (2010). Analysis of the influence of self-efficacy on entrepreneurial intentions. Prospect, 9(2), 14-21.

De Jong, J., \& Hartog, D.D. (2003). Leadership as a determinant of innovativ behaviour: A Conceptual framework.

De Jong, J.P.J., \& Kemp, R. (2003, June). Determinants of Co-workers's Innovative Behaviour: An Investigation into Knowledge Intensive Service. International Journal of InnovationManagement, 7(2), 189-212. https://doi.org/10.1142/S1363919603000787

Drucker, P.F. (1993). Innovation and Entrepreneurship. Harper and Row: New York, USA.

Drunovisek, M., Joakim, W., \& Mellisa, S.C. (2010). Entrepreneurial self-efficacy and Business start-up: Developing a Multi-Dimensional Definition. International Journal of enterpreneurrial Behaviour and Research, 10(4).

Ghozali, I.M. Fuad. (2005). Structural Equation Modeling. BP Universitas Diponegoro. Semarang.

Hsi-Chi Hsiao. (2011). The Impact of Self Efficacy on Innovative Work Behavior for Teachers. International Journal Of Social Science and Humaniora, 1(1), 31-36. https://doi.org/10.7763/IJSSH.2011.V1.6

Hsrich, R.D., \& O'Brien. (1981). The Women Entrepreneur As A Reflection of the Type of Business. Pp. in K.H. Vesper. Frontiers of Entrepreneurship Research.

Idris, A. (2008, April). A profile of Innovative Women Entrepreneurs. International Business Research, 1(2).

Idris, A. (2008). Cultivating Innovation Through Female Leadership. The Malaysian Leadership Perspective. Asian Social Science, 4(6).

Janssen, O. (2003). Innovative Behaviour and Job Involvement at the Price Conflict and Less Satisfactory Relations with Co-workers. Journal of Occupational and Organizational Psychology, 76, 347-364. https://doi.org/10.1348/096317903769647210

Justo, R., Cruz, C., Castro, J.D., \& Coduras, A. (2006). Entrepreneurs' Perceptions of Success: Examining Differences across Gender and Family Status. Institute de Empresa Business School, IE Working Paper, Vol. WP06-07.

Kleysen, R.F., \& Street, C.T. (2001). Toward A Multi-Dimentional Measure Of Individual Innovative Behavior, Journal of Intellectual Capital, 2(3), 284-294. https://doi.org/10.1108/EUM0000000005660

Kompulla, R., \& Reijonen, H. (2007). Perception of Success and its Effect on Small Firm performance. Journal of Small Business and Enterprise Development, 14(4), 689-701.

Lu, Hong, \& Da, Chen-Chun. (2013). Relation between Entrepreneurial Leadership and Innovative Behavior: The Mediating Effect of Entrepreneurial self efficacy an the moderating effect effect of openness to experience and extraversion. Information Technology Journal, 12, 1035-1044.

Mokhtar, M.Z., \& Syahida, N.W.I. (2012). Marketing Strategies and the Difference Level of Sales and Profits Performance of the Batik SMEs in Malaysia. International Journal of Business and Management, 7(23). https://doi.org/10.5539/ijbm.v7n23p96

Momeni, M., Ebrahimpour, H., \& Ajirloo, M.B. (2014). The Effect of Employees Self Efficacy on Innovative Work Behavioral at Social Security Organization Employees in Ardabil Province. Kuwait Chapter of Arabian Journal of Business and Management Review, 3(8), 29-32. https://doi.org/10.12816/0018304 
Pinasti, M., \& Wiwiek, R.A. (2016). Co-opetition To Promote Growth Of Batik Small And Medium Entreprises. International Journal Of Business and Society, 17(3), 401-412.

Rani, S.H.A., \& Hashim, N. (2017). Factors that Influence Women Entrepreneurial Success In Malaysia : A Conceptual Framework. International Journal of Research in Business and Management, 4(1), 16-23.

Scott, S.G., \& Bruce, R.A. (1994). Determinants of Innovative behavior: A Path Model Of Individual Innovation in the Workplace. Academy of Management Journal, 37(3), 580-607. Sugiyono. 2014. Metode Penelitian Kuantitatif \& Kualitatif dan R \& D. Bandung, Alfabet. https://doi.org/10.2307/256701

Setyorini, C.T., Pinasti, M., \& Rokhayati, H. (2013). Strengthening the Internal Factors of Batik Cluster SMEs in Indonesia: A Case of Six Districts in South-Central Java. International Journal of Business, Humanities and Technology, 3(1).

Sunday, S. Babalola. (2014). Women Entrepreneurial Innovative Behaviour: The Role of Psychological Capital. International Journal Of Business and Management, 4(11), 184192.

Zhao, H., Seibert, S.E., \& Hills, G.E. (2005). The mediating role of self-efficacy in the development of entrepreneurial intentions. Journal of Applied Psychology, 90, 1265-1272. https://doi.org/10.1037/0021-9010.90.6.1265

Zimmerer, T.W., \& Scarborough, N.M. (2001). Essentials of Entrepreneurship and Small Business Management. Upper Saddle River, NJ: Prentice Hill. 